\title{
THE JEWISH WALL: \\ THE EISENMAN EMPIRE
}

\author{
A B S T R A C T
}

In this article author is arguing that architecture, like all other aesthetic disciplines, has for long been pointing to the original problem: the sense of form. The form is seen as the multiplicity of expressive language that comes from particular kind of knowledge. Regarding this architecture is seen as work of realization; the cognition of knowledge and that the form is representation, the sense is the essence.

Author is also arguing that the greater variable, although not the only one, among the four factors concerns the right to knowledge. The greater or smaller its extension and profoundness, the greater or smaller our ability to slide along the essential line of the slope. Or, towards the "contents of the truth of one work", if we wish to use the same words of Walter Benjamin. But the hypothesis, although it has to be demonstrated yet, imposes the logic of thoughts, which should be added to the aesthetics of thoughts: the gift of compilation, the image of the unity of the entirety.In several parts of this paper, through the questions of the theological, the scene of thought, interpretation on representation and contemplation, ideas, concepts and phenomenon, author will discuss on possible interpretations of work of Pieter Eisenman. 


\section{PREMISE}

\section{THE QUESTION OF THE THEO-LOGICAL}

Architecture, like all other aesthetic disciplines, has for long been pointing to the original problem: the sense of form. An epistemological binominal in connection with another couple of notions equally fundamental: knowledge and work. Hence the equation: the sense relates to form same as knowledge relates to work. The work is a given thing in the entirety of its completed and effective reality. Cognition is the amplitude or the latitude of our knowledge in respect to the work. The form is the multiplicity of expressive language that comes from that knowledge. The sense is the metaphysical-theological unity, the maximum aesthetic density, ${ }^{1}$ the plastic-generative power of knowledge. In synthesis: the work is realization; the cognition is knowledge; the form is representation; the sense is the essence. Overall, that is: Architecture.

Naturally, the greater variable, although not the only one, among the four factors concerns the right to knowledge. The greater or smaller its extension and profoundness, the greater or smaller our ability to slide along the essential line of the slope. Or, towards the "contents of the truth of one work", if we wish to use the same words of W. Benjamin².

From this viewpoint the work of Peter Eisenman is absolutely emblematic. The perfect cryptogram for decoding challenges of our mind, same as the magic cube challenges our ability: its infinite combinations do not depend that much on Cartesian mechanics as much as on hermetic and hermeneutic sophisticated topology. One, but not quite an accidental enigma of a cube. Elevation to the third potential indicates a vector of difficulties, however, also the degree of protection or the level of sense concealment. The first level, actually, the most extensive as per diffusion and affirmation, belongs to the contemporary criticism with its dominant interpretation model of analytical-descriptive type. The second level belongs to the theoretical device of the author. The third level belongs to the underground relationship and contribution of the Jewish culture.

The more it climbs up, or the more it drowns, the more it passes from the real towards the essential ${ }^{3}$. Prophecy? Prediction? Presumption? Maybe! But the hypothesis, although it has to be demonstrated yet, imposes the logic of thoughts, which should be added to the aesthetics of thoughts: the gift of compilation, the image of the unity of the entirety. The silent sphere of Eisenman's work appears therefore suspended in front of the ridge of enigmas: 
criticism, cognition, culture. The work and enigma, aesthetics and knowledge, as "metaphysical" personifications in Magritte, are reflected immobile in order to carefully scrutinize their only invisible face: the mystery of sense.

Logics and analysis, aesthetics and contemplation, are therefore the tracks of thoughts which have opposite directions and diverse paths, however, thereafter converge towards a unique point where the "echo of the original can be awakened"5. That is the summit, which for Benjamin is just barely a touched connection between the authenticity of the work and the critical thought, where the fidelity of thought and the freedom of its interpretation coincide according to the unique law. It is a magic relationship as per the breadth, precision, sensitivity, which Berlin philosopher translated into efficient geometrical image of the tangent (the interpretation) and the circumference (the original ${ }^{6}$. Between the monad of the work (the circumference) and the infinite orbit of the thought (the tangent line) only for a moment there sparks the scintilla of the thought. In the nebulous encounter the fatigue and the hope of interpretative engagement are condensed and burn out.

In summary, there are two basic principles that the thought lasts in the function of the sense: that logical-analytical (the freedom) and that aestheticcontemplative (fidelity, if it is not the law). Neither is the other's alternative, however, they complement each other reciprocally. Each of them should respond in an autonomous and coherent manner to three-phased Eisenman's enigma (criticism-work-culture) while using also their own and specific instruments. The logics by means of philosophy; aesthetics by means of symbol.

Since telos of the work is the convergence of all goals in the unity of principles, if archi of the sense were to implode also the presupposition and the necessity of the initial demand would implode. Which is impossible since the logics itself cannot endanger the aesthetics. Therefore, to avoid the contradiction directly with logics it is necessary to separate a priori that previous ontological and epistemological condition capable of uniting together all other planes currently divided: philosophical, symbolic and formal ones. This common horizon constitutes that which we provisionally denominate as the theological plane.

The demonstration of the thesis on the sense of the form within the theological, however, as already mentioned in the first indication, uses the critical thought of Walter Benjamin. For at least two reasons. The first one, due to intellectual affinity: the common root of the Hebrew culture of the German philosopher and the American architect. The second one, due to theoretical affinity: the 
undisputed innovative role by now acquired from their works in contemporary culture within two close and complementary disciplines of art criticism and the criticism of architecture.

But in order to pull taut the arc of Eisenman's work with the cord of Benjamin's thought, we have immediately to put aside, for better security, two short scripts of the exiled Jewish intellectual: Theological-political fragments from $1921^{7}$ and Experience and Poverty from $1933^{8}$. Two robust theoretical threads: one aesthetic, the other one ethical.

However, in order to proceed, first we have to clarify the list of principal configurations of the thought, then their correct disposition on the scene of knowledge and finally the interpretations of the sequence of thoughts:

The list of principal configurations of the thought.

The horizon: theological order of work.

The sight: the sense of the form of the work.

The means: the interpretation of the thought: the arc: Eisenman's thought. the cord: Benjamin's thought. the sight: logical-contemplative thought. the arrows: logical vector, symbolical vector.

\section{THE SCENE OF THOUGHT}

The particularity of the sight, first of all, lies in being positioned between the horizon and the aiming point. That is, the sense of the form in its essence is on the sight - and admired - from two extreme positions, from two opposed and diverse orders ${ }^{9}$ : from the indomitable theological and from the evincible profane. From the order of profane the logic vector is started; from the order of theological - the symbolic vector. The vectors have natural specificities and opposite directions but they converge towards the same target. Only in their perfect contact the image of sense can be incited. Therefore, the sight does not have only one face - the one simply turned towards us and our knowledge, but also possesses that apparently hidden and invisible revolt towards revealingcontemplation. From two-dimensional towards three-dimensional, the horizon is just because of that spherical. The sense, thus, reveals the plasticity of the spiritual abstractness in the formality of the work. Their blending permits unfolding of the contents, the "internal form" 10 , actually the matrix of the contents of the external form. Namely, of the presupposition of that area. 
The sequence of interpretation of the thought: prologue, dialogue, epilogue.

A. Prologue was given to the critical-philosophical thought of Walter Benjamin; the language plot was set and the constellation of the theological-metaphysical profane area.

B. Dialogue was conducted through operative figures of critical-theoretical thought of the architect Peter Eisenman.

C. Epilogue was devoted to the sense of Eisenman's work resulting from overlapping and self-reflection between the dialogue and prologue.

\section{A - PROLOGUE}

\section{BENJAMIN: ICONOLOGY OF LINKS}

There is no other possible and plausible condition but to depart from the initial binominals: sense-form; knowledge-work, analyzing particularly the significance of interpretation, to frame attentively the primary standpoint of our view as regards the work.

\section{INTERPRETATION - REPRESENTATION - CONTEMPLATION}

In the postulate of Goethe's essay Elective Affinities, Benjamin clarifies from the very beginning the difference of the meaning contained in the notion interpretations by comparing two only seemingly close words: the critique and comment. The first word searches for "contents of the truth", it is contemplative; the second one searches for "its real contents"11, it is descriptive. But between these two words "that fundamental law" has been instituted, so that, the greater "the contents of the truth of one work, the closer and more invisibly it is linked to its real contents" ${ }^{\prime 2}$. Naturally, the real contents remain on the surface in respect to the profound stratification of the contents of the truth. For that reason the critic is like a "paleographer in front of the parchment whose text has faded ${ }^{13}$ and is covered with the signs of yet more powerful script" ${ }^{14}$, (the prefect predicament of Eisenman's work). But before the flare of the "burning story" 15 the interpreter masks himself. The commentator wears the mask of the "chemist"; and the critic the mask of the' "alchemist". "The chemist searches for the elements of the combustion. The alchemist, for the secret of the flame still burning" ${ }^{\prime 16}$. It is clear that the chemist has undermined the alchemist, the meaning of the sense, and the science the theology. And thus "not presence, but the sense $e^{17}$ of the real elements in the work, almost always remains concealed. But since the eternal nucleus of the work emerges from their frameworks, each contemporary critique, no matter at which high level it might be, gathers in 
itself more moving truth than immobile one, as well as more temporary effect than the eternal being" $"$.

The critical interpretation should address within the frame of the veritable. It must know to progress in the profound layers of the sense fixed in the appearance of the real in order to at least find the moving truth of the eternal nucleus of the work, in that place where the indestructible presupposition of the form dwells, the reign of the "absolute sovereignty of the relations"19.

Critical interpretation can only be followed by the representation. Each one complements the other, like the elements of the ladder. The representation corresponds to the parallel supporting poles; and the interpretation to the ledges. In their assembling the vertical continuity of the supporting poles and horizontal discontinuity of the ledges form the steps, along which, and only in this way, the knowledge may stream guaranteeing proper reinstatement of thoughts. Also, by evoking the Biblical image in the Genesis 28,12, if the borders of the ladder, its points of support would be positioned within the reign of the truth and the empire of the real then we could also be able to imagine that the supporting poles descend from the paternal sky and that terrestrial mothers climb up these ledges. The metaphor of the ladder, besides visual representation of the overall principle of the continuity of the aesthetics and the discontinuity of the logical, shows the unity of relations and hierarchy of knowledge, or the medium and of that still incomplete which belongs to the part between the theological unity and the historical multiplicity.

In the epistemological premise in the German baroque Drama ${ }^{20}$ the problem of representation, as a presumption of the philosophical doctrine of idea, recognizes this dual movement within the knowledge: of the truth and the things. The difference between the poles, between the veritable and the scientific knowledge, results just like enormous in the logics itself. The contemplative way presupposes the unity and can advance only in the perceptible, in the aesthetic. The analytical way presupposes the multiplicity and may advance only according to the sum of concepts. It is derived from it that the truth may be expressed only by the way of representation; whereas knowledge may be expressed only by presentation ${ }^{21}$. The particularity of the representational method, therefore, is to be in an "indirect way" neither linear nor sequential, but always original. Each time it "resumes continuously from the beginning, returns with full attention to the same thing. This methodical and rhythmical movement of the respiration is to be a special way of contemplation"22. Just like that undemonstrative-inviolable-invisible even though it appears in percentage 
partial and reduced to the perceptible semblance. As a consequence at the end of the representation we find an idea; and at the end of the concept, we have phenomenon. However, beyond any logics of discourse the "representation should find its own redemption" 23 in the image of the work (the sense of form), in full expressive maturity between the theological form and profane.

\section{IDEA-CONCEPT-PHENOMENON}

One should not, however, forget the initial question in respect to the dual binominal: sense-knowledge, form-work. For Benjamin the only offered possibility of plausible research coincides with maximum aperture of the view (thought) of «all range of the theme». For at least two reasons.

A. in order to magnify the spectrum of knowledge.

B. in order to "first let the hypothesis guide: which appears diffuse and heterogeneously may offer, in the light of corresponding concepts, the elements for synthesis" ${ }^{24}$.

In this lies previously announced philosophical doctrine of Benjamin's ideas. The idea-concept-phenomenon triad already reveals the elements, limitations and syntax between the extremes. The unity of the idea, on one part, and the multiplicity of the phenomenon, on the other part. The concept thus has a "mediating function" 25 in realization of the connection between the idea and the phenomenon. Its task is to extrapolate the value of the elements put in light of the empirical facts with maximum precision. To remind: it works in an analytical manner. Therefore, the phenomena "determine, for existence, commonalities and differences, the scope and contents of the concepts which adopt them"26. Or, all together, belongs to the variety and transience of the world of facts. On the extreme opposite side, however, there lies the universal idea $^{27}$. Enlightening only in the contemplative way, and by that free from all analytical and "intuitive" 28 types, "the idea can be defined by configuration of the link that the unique and extreme possess that which is similar to them" 29 . There, thus, exists an intimate and unbreakable similarity between the idea and the phenomenon which passes through the filter of the concept. The phenomena, therefore, are saved from the collapse of transience just by virtue of the representation of the idea. They, the ideas, are "the eternal constellations" 30 . In fact, "the ideas relate to the things same like the constellations relate to the stars" ${ }^{\prime 3}$.

But that which should be emphasized most evidently and which is sensed as the rumble of the underground wave actually concerns the syntax of the present 
limitations in the triad. For Benjamin the knowledge which forms the work of art reaches you in two completely diverse and opposed ways, although amalgamated and convergent. That logical-analytical which relates to the scientific knowledge reaches through the cumulative progress of the concept, and that epistemological-contemplative which relates to philosophy, reaches through the representation of the ideas "in the medium of the empirical" 32 . Therefore, the unity of knowledge expands as far as the search of the most remote and the most secluded fringes of extremes. And that is exactly the factor of the amplitude of knowledge which should pass through the coefficient of unity-density-brightness of the thought. With an unexpected reversal, first of all because of our contemporary culture: only that aesthetically theologically oriented can legitimize the logical, and not the contrary.

Therefore, let us provisionally try to summarize some considerations.

A. the metaphysical is consubstantial to the physical, the very essence of the real.

B. the aesthetic is the indispensable ontological plane for each thing, each work.

C. the formal and theoretical elaboration has submerged any "rigorous thought" ${ }^{\prime 3}$.

However, we still have to remain within the idea of divine (the infinite and immaterial) and continue with Benjamin's logical-theoretical perspective.

\section{TRUTH-ORIGIN-CREATION}

In view of the ideas being non-cognizable by logical-analytical way but perceivable by the aesthetical way, by nature of things they belong to the domain of truth, being itself non-cognizable in itself. In fact:

A. "The truth never enters into relationship, and even less in the intentional relationship".

B. "The object of knowledge, which is determined in conceptual intention, is not the truth. The truth is the unintentional being formed from the idea".

C. "The structure of the truth, therefore requires one being, which, by its strange intention, resembles that pure and simple in things, but consistently surpasses it".

D. "The truth does not consist of the intention which it would find in its empirical determination, but it is the potency which shapes the essence of the empirical" ${ }^{34}$. 
So, if within the truth, the way it appears in Benjamin's sequence, there is the culmination of the sense, even if for a moment the sense remains blurred in the vague and indefinite aura, that which needs to be comprehended relates to the expressive modality of ideas in their relations within the truth. For Benjamin this modality is "the name": the only "being protected against any phenomenality, the only being to which such power belongs. It determines the expression of ideas. But they are not expressed as much in the original language, as in the original perception, in which the words would not lose their denotative aura in favor of cognitive significance" ${ }^{\prime 35}$. So, the words (but already before the first letters of the alphabet, as we will see, and we are already in the temple of the Jewish culture) are the original matrices of the combinatorial expression of ideas. That means that it makes the passage of the unintentional power of the truth possible as far as the aesthetical. In fact, "idea is something linguistic, more precise: something which in the essence of the work coincides with that moment for which the word is a symbol"36. Let us repeat that in order to make a concept: the word is actually the first original link of the predicament derived from the magic contact between the power-and-esthetical. And just "by means of the representation the words symbolic character adds the idea of self- transparency"37, namely the exhibition to our intellect. Therefrom and further on, the iconological chain of connections traverses form idea of the image to the form restituting the totality to the intellectual and phenomenal world. Something analogous to the idea of "platonic salvation"38.

But what must be understood now regards first of all the scope and structure of the symbol in Benjamin. First, it is about the "theological competence" and "allows it to penetrate all forms of art in depth" 39 . It possesses four principal requirements: "the momentary, the total, the inscrutable, the necessary", to which "clarity and brevity" ${ }^{40}$ must be added. In other words, the symbol is:

$A$. anticipation or pre-vision;

B. concentration, the capacity to comprehend from the glimmer the whole from the beginning;

C. condition, the background of the origin of the images and their meaning;

D. action of the meaning;

E. representation of the meaning

F. attribution of the meaning.

Therefore, symbol has nothing static or sclerotic, not even sentimental or romantic, being first of all an active principle which renews the original Biblical fiat into the infinite aesthetic fiat. Precisely because of its "magic affinity" between the incommensurables, between the "infinite" real and "immediacy"41 
of the perceptible, just because of its inner capacity to "be the momentary totality" ${ }^{\prime 2}$ it is attributed to the theological frame. The notion which, however, requires immediate, although not the provisional clarification. In fact, the theological should not be considered here in the historiographical sense of revealing the tradition. Instead, it indicates to the supreme and sovereign level to which an indivisible and inviolable plane of the aesthetic corresponds, the unconditional appearance, the reign of the connections and all relationships (purely perceptible). For that reason since the very beginning we have used the formula "theological" - the way it appears - in order to recall in the word the evocative meaning preserved in the Greek root (theòs-theoi) indicating to all those inherent meanings contained in perception and seeing the original.

There is no other alternative for understanding the world. For Benjamin the course of the actual history cannot be separated from the authentic reflection on the idea of truth, hence the consequence is the analogous and parallel theme of the origin. The dialectics of the opposites between the actual history and the actuality of the origin in order to be deployed in its full efficiency must traverse through all stages constituting the real - the spiritual: unity-multiplicity; ideaphenomenon; contemplation-domination, etc. The plurality of things can be preserved only in recognizing the constellations of ideas through contribution form the description of reality, and the existence of ideas, through symbolic characters of the words, finds the possibility of its own transparency. Since "philosophy cannot pretend to talk in the tone of revelation" but rather "through reminiscence which goes back first of all to the original perception" ${ }^{43}$, only like that "in philosophical contemplation the idea is liberated like the word from the most intimate nucleus of reality (...) to claim back its right to nominate" ${ }^{44}$. We find ourselves precisely in front of "Adam's" dimension, in the first Book of Genesis, the Jewish Bereshit, in which it was stated "the state of Paradise is still unengaged to struggle with the informative significance of words". "Thus philosophy (...) is rightfully, throughout history, the struggle for representation of certain words, always the same ones: ideas ${ }^{45}$ ". Thus "the philosophical history as the science of origin is the form, which from the remotes extremes (...) finds the configuration of the idea as a marked totality of coexistence of those opposites" ${ }^{46}$.

To insist on the origin is equal to subtracting the notion from the beginning of each initial static concept and thereby also the thought reflected from the superficial and hasty conclusions. Therefore, let us return to the sequence of Benjamin's points of this semantic scale.

A. "origin is an entirely historical category"; 
B. "it has nothing in common with the origin (genesis)";

C. "in origin it is not intended to become that which flows, but that which becomes from flowing and passing";

D. "origin lies in the transience of being as the vortex and drags in its rhythm the material of its own origin (birth)";

E. "in the factual original it never allows to be recognized and its rhythm only opens up with dual vision: between restoration-renovation and imperfect-incomplete";

F. "in each original phenomenon the form is determined in which idea continues to confront the historical world, as long as there, it has been completed, in all of its history";

G. "origin does not emerge from the facts although it concerns their prehistory and the successive history";

H. "in each essential process of the unity and repetition condition each other";

I. "authentic is the property of the origin of phenomenon, and it is the subject of the finding which coincides with the act of recognition".

While the historical category is confirmed the origin oscillates between the theological dimension of the ideas and the profane dimensions of phenomenon, between the revelation and redemption, so that it is the ontological content. Then subtracted from each illusory fixity the origin permeates constantly saeculum, the Jewish 1' 'óLaM: that longest time although assigned to elaboration and realization of the Project of the Semitic Elohim ${ }^{47}$. The concept of origin, however, cannot remain isolated and autonomous as if it were an ontological category in its own right, but must be placed in the visual cone of another condition, anterior or posterior at the same time, between the presupposition and the end, which knows how to contain it, support it, perpetuate and illuminate it.

We cannot forget, right now, the general configuration of Benjamin's thoughts. The real, that which we consider the concrete-factual world, is the set of all infinite gradations between "the spiritual being and the linguistic being" 48 . Namely, the real is the set of all expressive planes of the aesthetic, the entire range of links that connect the ends: the scope of theological, the scope of phenomenal. "The language reality (...) extends (...) to all (...) without an exception. There is no event or thing in animate or inanimate nature (...) which does not (...) communicate its own spiritual contents" ${ }^{\text {"49 }}$. Expression and expressive are also valid, and mainly, for all man's work, when they are exactly such. However, "equalization" between the spiritual being and the 
linguistic being is "metaphysically so important" to conduct "spontaneously" the "concert of revelation" 50 . The concert which we learn about only through linguist creation. But in the revelation-linguistic creation binominal there is a triple law:

A. the revelation «does not know the inexpressible ${ }^{51}$;

B. the linguistic creation lives in the "contrast between the expressed and expressible, between unexpressed and inexpressible" 52 ;

C. the language is "the creative medium", the "creative force" $"$.

"Language is that which creates (...) that which achieves" 54 . For those reasons the Bible, particularly in the Book of Genesis (Bereshit), becomes practically "irreplaceable" 55 for Benjamin, not as a paradigm of the truth revealed, but as its intimate and profound relationship with the word "in its inexplicable and mysterious denouement" 56 . In fact, when language loses "its divine actuality (...) it becomes knowledge" 57 , when it loses the "immediacy of the name, it falls down into abyss of mediation, empty word" 58 .

The creation, as the projected act of the divine precedes and includes all original conditions and evolution with an aim to act as cosmic heartbeat: in the denouement of the origination of the language and in fatigued preservation and renovation of the pure, magical nucleus, the word itself, the letter revealed. That is, the creation (in TaNaK) works theologically through dual register: between the evidence of the "communicable" and the non-evidence of the "non-communicable"; between that which "symbolizes and the symbolized"59.

Let us make a summary for further clarification of the sequence of Benjamin's points $^{60}$ :

A. "spiritual being of man and things is the language";

B. "in the language there happened the creation";

C. "the creation took place in the verb";

D. "the verb is the linguistic essence of God" (YHWH - Elohim);

E. "each human language is only reflected in the name of the verb";

F. "the name is reduction of the verb same as knowledge is the reduction of creation".

Now, if our thought would be allowed only for a moment, in a hypothetical flash of mind to be able to follow the movement of the principle of creation of the theological order towards the aesthetical order, or if it would really be possible for our nous to grasp the point of passage "from the true to the apparent" ${ }^{\prime \prime 1}$, we could see or recognize in the principle of creation four plastic 
properties at minimum which innervate the work:

1. The work as "given shape",

2. The work as "expressionless",

3. The work as "the relief form",

4. The work as "morality".

"Maybe (...) all works of art have in themselves some way of creation as their contents" ${ }^{\prime 2}$. In fact, in the appendix to Goethe's Elective Affinity, Benjamin repeats with care that "creation is one of the most powerful themes in art" although the work of art cannot be "created" actually as "something given shape to" and, although the relationship between these two cannot follow trivially the "model of cause and effect". In creation it is implied "a priori metaphysical of salvation" whereas in the "shaped" linguistic forms the work of art appears mostly as the representation of that salvation. However, "an entire class of forms could be indicated (...) which deals with creation and in which the theme of creation emerges to light after having been subjected to the variation of intuition. Maybe these will differentiate due to the presence of a particular dimension of expressionless in them (...). The form (of these) works, whose theme is creation, can be defined as relief form. It concerns the forms that apparently contain a lot of shade and lots of disarray, like the interior of cable, embossed and hammered with certain relief metal works" ${ }^{64}$. This extraordinary description of Benjamin's which pushes us towards recognition of the ultimate property of work: when the relationship between creation and modification, between the essence and the perception of essence, between the life and existence, indicates to that "point of detachment" which is a pure "moral act" ${ }^{\prime \prime}$. And it is just "the morality (theological) of creation which gives the work the mark of expressionless" $" 66$. Thus the principle (the project) in creation (in Genesis) incorporates in it the role of moral ontology of the aesthetic. But the expressionless must not mislead us. It is not dull, matt, neutral language which ensues from profane frame of the work. Exactly the opposite: it is prime, vigorous, rigorous, precise, bright language which belongs to the theological frame of the work. "In expressionless is shown the sublime power of the truthful (of the unintentional truth), same as it is determined, in accordance with the laws of the moral world (of the theological relation) the symbolism of the existing world. (...) Expressionless, actually, (...) leads towards completion of the work, reducing it to one piece, in a downwards totality of appearance, which is a gross fragment of the real world, the fragment of a symbol"67. Anew and surprisingly there surfaces again the symbolic, the vital link of the work which flows incessantly between the "inhibition" of the truth and "tremor" 68 of the beauty, between self-denial of the subjectivity and self-transparency of the image in the work. 
The sketch of the constellation of Benjamin's thought delineates the new background of the knowledge on which now Eisenman's work will be projected. The importance of such epistemological background should not be underestimated: it meets not only the primary epistemological needs but maybe, the simplest one, the need for clarity. It could not exist, in fact, either a thought or the knowledge tout court, implicit in absoluteness and shared in universality. To distinguish and relate critical-interpretative thought to referential and appertaining knowledge is the equivalent for subtracting two notions, not the synonyms, from their general indetermination. It signifies recognition of movement of the thoughts own freedom in respect to the universe of knowledge in the mass of its own law. That which does not happen within the aesthetic. In Architecture, the determining plane of which is the aesthetic, we are immersed in the midst of epistemological paradox: a part of the phenomenal exceeds the entire metaphysics. In fact, technical-socio-scientific knowledge is a dominant paradigm (in the discipline like contemporary critique) even if it is a derivative (a part of all that) theo-onto-metaphysical knowledge.

No matter how much analogy still resounds suddenly between the theological language of the Berlin philosopher and the formal language of the New York architect, notwithstanding this statement there precedes a little demonstration. And since language corresponds to the unity of the impassable bottom, the socalled original Benjamin's - theoretical and aesthetic - preoccupation bounces in it: to value the unity of the work of art in the unity of knowledge. Namely, that is measuring the maximum density of work in maximum extension and depth of knowledge ${ }^{69}$. The same preoccupation is now valid for Eisenman's work. The work, therefore, is no longer isolated in the indefinable abstract and autonomous entity, but reflects epistemological-theological in the horizon. It is just from the progressive overlap and pressure between the force of Eisenman's work and the power of Benjamin's horizon that it emerges in progressively more sharp stratified and changeable profile of the sense: the figurative flow of idea. But, if the results of our critical interpretation can be appreciated or judged, as already mentioned, only in the end, also the beginning feels the impact of this same beneficial effect owing to the rays of the anticipated perception which attracts our mind and gradually cleanses the protective obscurity of the sense showing the tracks to be explored.

Critical interpretative thinking has thus been moved from the dynamic principle, the unity-relation binominal applied at diverse hierarchical levels: from theological to phenomenal, from representative to conceptual, from symbolic to abstract, towards the iconography of Benjamin's links. 


\section{B - DIALOGOUE}

\section{EISENMAN: ICONOLOGY OF WORDS}

The walled-up word: $I^{\circ}$ interpretative level

The end of the Classical ${ }^{70}$, Eisenman's essay published in 1984, can be taken as a theoretical emblem of his entire work. Written, intended and proposed as the minimal linguistic unity in respect to the maximum semantics unity, condenses in its pages the overall projection of Eisenman's work to expand it further with metaphysical backstroke in the orbit of epistemological-theological horizon. The particular force of the essay lies precisely in the modality of construction of the text by using two absolutely distinct linguistic registers: the first evident one, logical-abstract; the other non-evident, theo-logical-hieroglyphic. The first one, the historical-analytical, works on the plane of the reinforced chronological temporality with the exceptional sensibility of logical-abstract. The other one, the profound hieroglyphic (see epilogue) operates instead in the substrate of that same plane, through symbolic temporality and latent theological sensibility.

We are therefore obliged to proceed in two stages never forgetting Eisenman's distinct appearance: his dual and innate ability of simulation and dissimulation by means of language. To blind from a flash in respect to how much it must remain secret and walled-up in the original word.

\section{The word halved: $I^{\circ}{ }^{\circ}$ interpretative 1 evel}

For Eisenman the three big fictions ${ }^{71}$ which characterize the overall development of the classical and modern architecture are:

- Representation as an idea of Meaning,

- Reason as the idea of Truth,

- History as the idea of the Eternal.

They cannot be considered to be valid any longer given that in the meantime they have modified so radically the foundations of the contemporary knowledge. Accordingly for that reason any epistemological presupposition was lacking, and thereby the absolute ones, out of which those same words were derived.

In response to this classical model, ineffective and outdated but still prevailing and universal, Eisenman proposes in fact ${ }^{72}$ one alternative non-classical model. The idea about presence is substituted with the idea of absence; the 
architecture of the image he opposes to the architecture of writing ${ }^{73}$, of $t e x t^{74}$. One post-scriptum definitely closes the essay The End of the Classical same as the large tombstone bars the tomb. In the letters of epigraphs it is reflected only that which must or should still survive in the discipline:

- The architecture without time, without origin and purpose;

- non-representative architecture, without object;

- artificial-arbitrary architecture, deprived of reason.

Eisenman's text although presented superficially in its apparent and finite clarity sinks into the impenetrable obscurity as soon as one starts examining it with more attention. The difficulties in interpretation then multiply to the point where they are transformed in the real inextricable barrier if the text is placed in relation to his entire critical/projected work.

Which meaning should we then attribute to architecture invoked as artificial, arbitrary or non-representative if already the contemporary knowledge (and thereby also architecture) suffocates and gasps in the dissolve and insignificant magma of our time? Are we not in the West for many years in the middle of nihilistic fractioning and dissolution due to its ontological a-aesthetic, a-metaphysical, a-temporal categories? And even if that were not so for what reason would instead Eisenman keep on writing and re-writing hundreds and hundreds of pages (which is an exception in the history of architecture if canonic tracts are excluded) to explain (and fold) in a judicial manner such detailed and minutely detailed each of his gestures or projected action enough to wish to remove (his) architecture from any possible arbitrary interpretation? Paradoxically, then sealing the arbitrariness in the cage of iron rationality? Are we then faced with the blatant contradiction, with a logical paradox, with semantic confusion, or simply with auto-referential style? Or maybe we still do not have a slightest interpretation code?

Among the many causes that contribute to determining these difficulties in interpretation, for now, we can single out at least two. The first one relates to the language of words. The second relates to the language of form, being architecture, just because of the expressed Eisenman's wish, writing. Both in the first and the second case, meaning, the contents of words and the form, the two typologies of writing or two grammars of the same language, join us halved by rational wish. In fact, as the words and the forms both alike come, for a moment, from the unique and identical field: profane-phenomenal, experimental-cumulative analytical knowledge of the concepts. 
We are exactly in the center of gravity of Benjamin's concept. Although we have understood, right from the Berlin philosopher, that the contents of the concept cannot reach in any way the veritable knowledge of the work of art, since the concept as per its nature is only part of that knowledge. Concept is a medium: one "tra" (or between in English or zwieschen in German) of the phenomenal world and the theological world. The word, thus, be it imagined, pronounced, written or drawn, does not enable us to comprehend and does not reveal its veritable nucleus if it joins halved. The absence of that presence (missing of that half), or the absence of the theological field in profane deprives the word of its own authentic contents - the sense - forcing it to wander silent, lonely, confused, in the infinite number of meanings and interpretations.

Therefore if the synecdoche of The End of Classical, and the more so the entire work of Eisenman, is read in its isolation, separated from epistemological field, it cannot do anything else but simulate and conceal at the same time. To pretend to be saying that I would conceal and not to stun the sense into silence We can be repelled or attracted by this phenomenal construction (fiction) of Eisenman's architecture, same as the grandiose wall of his thought repels or attracts us: impressive and fascinating, terrifying and seductive. One archaic challenge: like between the angel and the demon; between shame-theological and prejudice-logical.

\section{The word hieroglyphic. III ${ }^{\circ}$ interpretative level}

Not only are the words walled-up and halved, but they are also sealed. Probably to protect "the principle of knowledge. It is worth mentioning, from the beginning to reduce the prejudices automatically linked to the names" Even more than Kafka, Eisenman will never be able to directly write the word "Jewish" in his theoretical and critical essays, nor will he ever use it in his contents. Like the tree of knowledge planted in the center of the garden of Eden, it is analogously a forbidden word, likewise as it was forbidden to mention the sacred Tetragrammatons' of God: YHWH. However, God is always "Jewish". But even in this intimate preoccupation of "realism" " there may be resonates the ineradicable theological precaution. And it is precisely Eisenman, despite his tacit and unconditional prohibition, who entrusts only one single time the sound of the spoken word, the oral word and not the letter or the sign of the written word, with the opportunity to prefigure some points of the theological map. In any case a brief and subdued invitation, to lead us unexpectedly beyond, namely, as far as the top of its defensive theoretical wall. In February 1985, just shortly before finishing writing the essay The End of 
the Classical, the British magazine Blueprint published the interview of Janet Abrams with Peter Eisenman: (MIS)reading between the Lines. Confession seems more important than dialogue, and History seems to speak more than Author. In the short space of six columns the grand questions of Jewish metaphysics are disseminated and, and although they are inserted in their dialectical context they mark, however, the aspect of doctrinal norms. From that interview, the following essential themes are presented:

- Image: "not a Jewish idea" (although Greek - Christian) ${ }^{77}$;

- Word: "comes first from the Nature and from God since in Judaism there is no figure of Christ or Resurrection; and if the Word comes first, then it is more important to play with Word than with Nature or Reincarnation or with any other symbol coming from the Greek-Christian tradition";

- Text and Misunderstanding: "appertain to Jewish heritage, particularly to the interpretation structure which is manifested precisely in the relationship between interpretation of Torah (Text, the written law), Talmud (the collection of oral laws, interpretation of written law) and in the end Kabbalah (interpretation of interpretation, hermeneutic reading which insinuate itself among the lines of Torah)";

- Absence: the verb to be in present tense does not exist in Hebrew; "was" and "will be" exist. Therefore, there is no presence, but only "absence".

- Breaking of Greek-Christian axis: "for Architecture which strives to stand outside Greek-Christian tradition".

- Dislocation of Classical space: "hierarchical, symmetrical, closed, Euclidean; the principles on which the tradition of Greek-Christian thought in Architecture has always been based". "Architecture that is not interested in Origin or metaphysics (classical), but in Theology, since it speaks about Diaspora, of wandering. Without the necessity to return to Origin because of this".

Three considerations emerge immediately. The first is that architecture was removed from the neutral and ambiguous background of technical-scientific secularization. The second is that architecture was presented on the grand scene of Jewish tradition. The third is that Jewish aesthetics openly challenges the dominant tradition of Greek-Christian aesthetics.

In other words: a real clash, the highest, between the Jewish theology and Greek-Christian theology (philosophical) fought in the ambiguous scientific field of Nihilism. 


\section{C - EPILOGUE}

\section{THE WORK: ICONOLOGY OF FORM}

\section{Linguistic exodus}

Eisenman's language is not, does not wish to and cannot be directed. Instead, it should be protected against the triple clamp of the word: oral (sealed), written (halved), formal (hieroglyphic). But the levels of protection assigned to the word, and thereby to writing (architecture like writing, like text!), maybe do not indicate, per symmetrical reflection, the hierarchical access to the sense? And is this not an initial presumption so that paradoxically it is not lost the intangible reservation of the sense and its irradiated power in improper language? And which semantic key it would be able to open the closed word if not the codes of Jewish theo-logical culture?

If we would imagine now that we can superimpose the essay The End of the Classical to the interview (MIS)reading between the Lines as if they were two hypothetically acetate sheets sprinkled with indecipherable signs, we would be affected by the same surprise effect which is obtained by putting binocular on fire: we remain amazed or at least fascinated by the sudden sharpness of the image resulting from an unexpected landscape. We will finally be able to comprehend that Eisenman's writing can reveal a large richness of its own contents only if it is attentively observed in its transparency Namely: only if his writing is illuminated from the back (by that which is in front of us), the light source from the background of the Jewish thought. In particular, from the non-exhaustive, even though erroneously considered extinct, theological horizon.

The End of the Classical, therefore, is no way the death sentence for Architecture in general. One chapter closed, another one opens. Rather, that is the first act of theoretical proclamation of the Jewish authentic Architecture, free from the burden and abundance of the authority impressed in the Greek-Christian thoughts of the entire history of the West. Under the apparent and generic category of classical (both noun and the adjective) thus the vaguely absolute principle does not stagnate which should be replaced with the equally vague absolute principle of non-classical. Under the word classical shines instead the mature conscience of the Jewish paradigm in the open antagonism of the Greek-Christian paradigm. In other words, two diverse powerful sensibilities or theoretical-aesthetic visions, one facing the other, in the decisive struggle waged at the highest possible level: theological-philosophical, which, not to be 
forgotten, is pure epistemological plane of the aesthetic. The non-deferrable plane in Architecture.

Eisenman's declaration that architecture is without the end and without the origin, deprived of object and the reason, summarizes in fact in the extreme triad of the secret map of Hebrew thought, its pilgrim universal history. That statement, in fact, preludes if not already aspires to the new exodus: certainly not the people but the language. Not from Egypt but from the abundance (unbearable as the desert) of the Greek-Christian paradigm. But where to go, towards where? Towards the promised form. Towards the presence of the absence, the expression of the suppressed and unexpressed sensibility. In fact, the use - on the part of Eisenman - of negation and placing the suffixes in front of the names does not indicate in the symmetrical reflection the use of opposite meaning. Instead, he wished to express an intimate appeal of an absence, inner necessity of the form which gives the own mind the necessary power of the first act in order to break away and escape from the domain of the intellectual and linguistic that is improper, and to reconstruct the coherent language by its own intimacy. Three Eisenman's assumptions could be then completed in the following way:

- for an architecture without origin and without purpose, like refusing Greek-Christian metaphysics,

- for an architecture non-representative, deprived of the object, like refusing Greek-Christian iconological tradition.

- for an architecture artificial-arbitrary, deprived of reason, like refusing Greek-Christian episteme.

With these integrated additions we could rewrite the initial there propositions in a brief form without altering the meaning, however, with a warning that for each of them the use of the adjective Jewish is implicit:

- for an architecture like theology

- for an architecture like writing

- for an architecture like creation

Eisenman's works now occupy in full Benjamin's scene like a sphere between two horizons: the theological horizon of the Jewish thought; the nihilistic horizon of the scientific thought. Two ways to reach the sense of the work were therefore ready some time ago, wide open before our eyes as an imposing cosmic scenography. But if until now we have walked the path of the analyticalconceptual way of the scientific-profane field (in particular with a written word), now we have to confront decisively the aesthetic-contemplative way 
of the theological-metaphysical field (with hieroglyphic writing). That is the unique way that is able to lead us near to the mysterious point of Eisenman's sense, but also to the painful and removed place of our contemporary thought.

The real, authentic works possess as per their nature the incorporated essential unity that is expressed through certain properties. They are: identity, authenticity and recognizability. The unity of their style (of the work and not of the author) is therefore linguistic-expressive principle in the function and guarantee of the representative requests. For that reason the style should save the variability of the case and the changing needs in invariability of principles. For that same reason the style, the original appearance of the language, must inevitably possess the inner nucleus that dense as to be able to retain, like in nuclear physics, the whirling orbits of the elementary particles of that language. In fact the nucleus theoretical of Eiseman's language is formed at the beginning of his design activity, in sufficiently long time span if it refers to his personal biography (between approximately 1967-87), or it is reduced to a flash if referred to the universal Jewish history. In any case that is a golden and privileged period of Eisenman's creation. The most profound and most complex in figurative invention can be synthesized in three extraordinary aesthetic ${ }^{78}$ pearls or in formal principles:

- The principle of abstraction, (from House I to House X);

- The principle of "El” Shape, (from House XI, to Fin d'Ou T Hou S);

- The principle of Scaling, $\quad$ (from Moving Arrows to La Villette).

More than principles they seem unknown ${ }^{79}$, at least for now, those pearls wrapped with the opaque envelope of logical-analytical word. In fact, when observed from the scientific-nihilistic side, they appear as abstract signs, autoreferential (the "sign of the sign" 80 ). If they are projected on the theologicalJewish background, they inevitably remove, as if by magic, the amazing and fraught world of the symbolic.

But before reaching the symbolic we should comprehend the background of the aesthetic dispositive, starting however from its secret "magic" all the miracle of aesthetic, its unalterable essence is precisely to bring the links form abstraction to figuration, from auto-referentiality to the symbol overcoming contradictions, fractures, typical lacerations inherent in the objectprofane-phenomenal world. Indeed, extending in accordance with the law of extreme - the thing and the theological - their indissoluble unity. In fact, if it is impossible to reconstruct this unit in a scientific logical rationale (as already demonstrated in Benjamin's prologue) then it is possible in the aesthetic, 
whose principal and command stretch between the original "immediateness" and historical "mediation" 82 . The aesthetic plane is composed then of the infinite contemplative levels which by synthesis we reduce to three:

$\begin{array}{lll}\text { - phenomenal: } & \text { the profane } & \text { the scope of sensible; } \\ \text { - enunciate: } & \text { the word } & \text { the scope of intelligible; } \\ \text { - spiritual: } & \text { the theological } & \text { the scope of noetic. }\end{array}$

This means that in each of the three formal principles identified above (purity, "El" Shape, Scaling) we find the presence of all aesthetic levels in the hierarchy of their gradations. Therefore, if the first level of phenomenal is an eyesore for evident formal differences in three phases of Eisenman's project ${ }^{83}$, we will focus now on the quality of the second level, the enunciate level.

But we must not fall into deception of the word (abstract or conceptual) while being immersed with our mind in the scope of the aesthetic, not having any other possibility then for our reflection except to use the only instrument at disposal: precisely the word. To avoid the pitfalls of its arcane magic, the ambiguity of its wear and the weaknesses of our language, we have to maintain firmly, before our eyes, the theological contemplative background of the Jewish paradigm as refusal and substitution of the Greek-Christian classical paradigm. The word in Torah is "creation"; in Benjamin it is the "matrix of original perception"; in Eisenman it is "first of all». But the primitive word became detached, from the divine it becomes a "simple sign", "the bondage of confusion", "Babel of the language" ". And as if it were enough "the origin of abstraction", referring anew to Benjamin, it should be searched in "the original sin". The word, therefore, as the bearer and wrapped in the aesthetic, extends its domination to all. It occupies the space and time compressed between the revelation and apocalypse, between the prophecy and completion. With one particularity: uttering of the word however directs the movement of the aesthetic towards its own goal (be it authentic or non-authentic). Then there appear the emblems of its obscurity and the titles of Eisenman's projects denominated as per common sense. House I, II, III...X, Fin d'Ou T Hou S, Moving Arrows and many more, allude to the remote figurative origins of their birth: the spiritual theological. The third level of the aesthetic.

In Eisenman the conflict between the Jewish paradigm and the Greek-Christian paradigm presupposes, even according to his own statement, the kaleidoscopic dualism between theology and philosophy. An antagonism with original certain metaphysical consequences, however, first of all the aesthetic ones. In fact the question is paradoxically figurative. Paradoxical due to complexity although 
we have to reduce it to the extreme simplicity. In fact, the Greek philosophy abstracts the truth developing then the anthropocentric iconological language. The Jewish theology, instead, figures the truth developing then the logocentric iconological ${ }^{85}$ language. These statements have their roots not only in the grand Jewish mystical tradition but also in the thought of the modern philosophy. For example, in the principal work of Franz Rosenzweig (1886-1926), The Star of Redemption. "Creation is now the portal through which philosophy enters the house of theology" the bridge between the extremely subjective and extremely objective" ${ }^{87}$. The Bible theology (of the Torah) and particularly the Book of Genesis (Bereshit) prepares then the universe of the aesthetic in its spiritual dimension: the maximum figurative density, where the highest peaks and the deepest abysses of the creative word dwell in their invisibility, in awaiting their elaboration. In the spiritual theological "the linguistic miracle of revelation becomes the sign of the Divine creation" $" 88$, conferring to the aesthetic the plastic tonality, three-dimensionality immaterial. Wishing to force the gaze of thought by the optical metaphor we observe that: if the theological is the pure plane of the aesthetic, the spiritual is the maximum focused distance available (namely, the predisposition) of the theological in order to place in focus the set of figurative codes of belonging.

From these evaluations emerges another consideration. The sum of three levels of aesthetic - phenomenal, enunciate, spiritual - express clearly the unity, tone and gradation of the Jewish figurative logocentric iconology, radically different from the Greek-Christian anthropocentric figurative iconology. Ontology of the aesthetic does not change: the aesthetics changes, given the different referential codes of the significant.

Following reconfiguration of the links between Eisenman's formal principles and the levels of the aesthetics, we face the question of the symbolic.

\section{The power of the creator}

The unity of work is the object of the initial question about the meaning of the form.

The unity of work is the sovereign relation with the multiplicity of phenomenal. The theological is the scope of the aesthetics of the unity.

The phenomenal is the scope of the aesthetics of multiplicity.

The aesthetic is the indivisible plane between the theological and the phenomenal. 
The symbol is the figurative medium between theological and the phenomenal. The symbol is the aesthetic complement of the logic concept.

The symbol is emanation of the theological.

The theological though, and we cannot certainly forget it now, projected on the horizon of the Jewish paradigm has as its substrate the ineffable "fabric" of the Torah (TaNaK). The Holy Book of Creation, the Book of the Revealed Word, considered as "the symbol of the symbol", "the infinite symbol", "the symbol of the cosmic law". But Eisenman is not directly interested, as per his own admission, in either the written law, actually Torah, or the oral law, the Talmudic interpretation. But in the interpretation of the interpretation. That is: the Kabbalah. Corpus Symbolicum for excellence of "the myth of the divine unity" which is at the center.

Torah-Talmud-Kabbalah forms the inseparable triad of the Jewish critique. We could simply draw the image of the equilateral triangle. Torah is at the vertical top, Talmud and Kabbalah are at opposite angles. At the bottom side there is profane world, Shekhinah, the "presence"; at the kathetes two forms of interpretation of the divine: the way of rational-legal in Talmud; the way of aesthetic-symbolic of the Kabbalah.

This scheme just outlined might it not invoke the other analogous scheme if not identical as per its structure which is at the base of our writing: the Benjamin's interpretative scheme? Do not we see the surprising concordance of their reflecting images even though they are separated by temporal sidereal distance? Let us try to superimpose them:

The Jewish scheme

\section{Torah}

Kabbalah

The way of aesthetic-symbolic

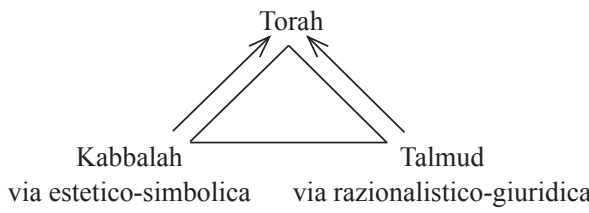

The Benjamin's scheme

The work of art

The theological

The way of aesthetic-contemplative The phenomenal The way of logical-analytical

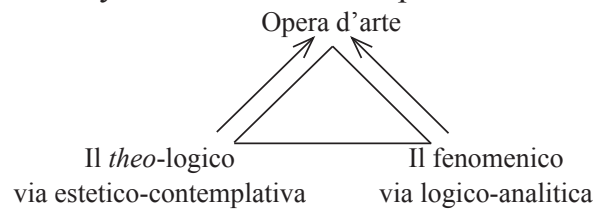


It seems evident that the immediate relation between Kabbalah and theological presented on the plane of the aesthetic; the mediated relation of the figures of the three Eisenman's principles first identified,

$$
\begin{aligned}
& \text { purity } \\
& \text { "El" Shape } \\
& \text { Scaling }
\end{aligned}
$$

and which conserve in the signs of their languages the spiritual sources of their noetic sources (the third level of the aesthetic).

Kabbalah has always been inscribed in this incessant movement between the immediacy of the theological and the mediation of the phenomenal. It has always had to reinterpret the history of people of Israel in relation to the principle of creation of the divine unity. A fever of life, the indomitable ontological fervor: having continuously to adjust the tragic events of the Jewish history in an ever new and coherent theological symbology. In fact the symbol was assigned a task to guarantee the contact between the original prefiguration and the origin of the world by registering the epochal events. The symbols of Kabbalah thus originate from the Bible perspective, between the revelation-catastrophe-redemption, intensified and awakened by Benjamin's theological thought.

In the rich repertoire of the mystical tradition the "visibility" ${ }^{89}$ of the symbols together with the theme of "creation" of the world, the original divine act, therefore assumes the importance and fundamental role. From this context there emerge, however, also three grand symbols:

\section{Sefiroth}

\section{Tzimtzum}

Shevirat ha-kelim 90

which with the triad of formal Eisenman's principles already establish the dual relationship: the immediacy of the aesthetic ; the mediation of the language.

Each symbol represents a process of cosmic generation declined in respect to the temporal or historical evolution. The symbols therefore follow the precise chronology and elaborate each time a diverse iconology.

$$
\begin{array}{ll}
\text { Sefiroth } & \text { the divine emanation, the time of innocence } \\
\text { Tzimtzum } & \text { the divine contraction, the time of exodus } \\
\text { Shevirat ha-kelim } & \text { the divine dispersion, the time of diaspora }
\end{array}
$$

In the first symbol, the process of creation, due to successive emanations and reflections comes through ten levels or elements of the divine wisdom. An 
"immaterial writing" which yet "impact and carve" the "primordial cosmos", the spiritual space between the unattainable God and the material world.

In the second symbol, the process of creation underwent a radical change to respond in an adequate manner to increasingly great sufferings and evil. The primordial creative act cannot reflect any longer that from the donor and that is why progressive expansion. The presence of evil implies now the profound revision of the theological: God, the unattainable wisdom, Jewish En-Sof, retreats "from himself for himself". The painful contraction of evil must make space for the good before expanding. The previous linear and wavy motion transforms forcibly into the oscillating movement, binary, cardiac.

In the third symbol, literally "breaking the vessels", dramatic escalation of the story now leads to a negative and irreversible apocalyptic vision. The preceding symbolic models of the process of creation collapse: the structure of the sefirotic planes, however, present in all three symbols, undergoes the definite destruction losing irremediably also the shadow of the original innocence.

The variations of the symbols must guarantee timely the link between the absolute divine unity and their everyday life. Between to be and being. Or, in the symbol there is an incessant repetition of the origin manifested according to Benjamin's categories momentary, total, the inscrutable, necessary, clarity, brevity, since the origin, taking up all that has been mentioned, "a fully historical category" is found in the incessant flow between theological dimension of the ideas and profane dimension of phenomena.

The relation, therefore, between the symbol of Jewish mysticism and linguistic principles of Eisenman's architecture is actualized in the work dragging through the swirling vortex of origination the material of its birth and sucking from the future of the history the material of its own redemption. The relation, the completed work, can be reduced yet on another three levels: aesthetic, linguistic, historical. Aesthetic, as the ontological-theological plane; linguistic, as the plane of expression; historical, as the plane of chronological actuality.

So we can see the ternary relations between the mystical symbols, Eisenman's principles and phenomenal reality how they use in parallel also the canonic Cartesian system: horizontally, the apices of principles; vertically, the ordinate of symbols, obtaining a double vector of chronological and aesthetic result.

\begin{tabular}{l|l|l} 
THE SYMBOLS OF MYSTICAL & EISENMAN'S PRINCIPLES & PHENOMENAL REALITY \\
Sefiroth (emanation) & purity & absence of place \\
Tzimtzum (contraction) & "El" Shape & presence of place \\
Shevirat ha-kelim (dispersion) & Scaling & fragmentation of place
\end{tabular}




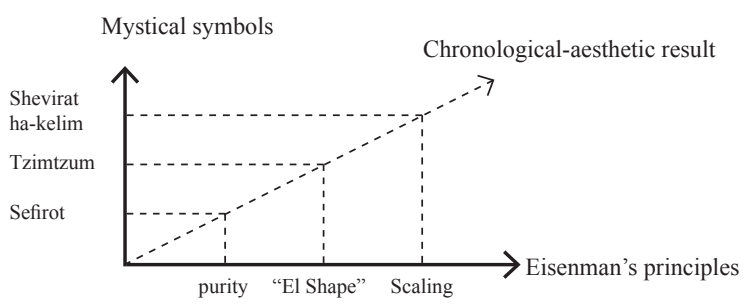

What is surprising and amazing is that Eisenman's formal principals undoubtedly originate from the innate logical-descriptive ability of the "real" but their expression, the linguistic stamp of signs, the essence (and not the appearance) of their visibility, depend exclusively and anew on being included in the projective cone of the cosmic symbolic power. From the horizon of the theological, and not the logical, comes the bundle of plastic forces to imprint on the surface of the things the "relief form" of the expression: the three-dimensionality of the aesthetic. The linguistic mark is an indelible imprint of symbols, the authenticity of form, the object of the "recognition" and of the "discovery". And it is precisely between these extremes, at the most remote margins between the revelation and redemption that the autonomy of the aesthetic plane discovers the reductionism of conceptual logics, revealing together the precise iconological parallelism and the perfect chronological sequence between the theological symbols and Eisenman's principles. The dual bond of origin.

The importance of Eisenman's work, its grandeur, lies, therefore, in the fact that it has stolen the reality from the improper domain of rational science and psychological expressionism and because it has brought to architecture the connection between the logical and theological in the unity of form through absoluteness of the refined representative method and, at the same time, surprising.

\section{Self-transparency of the unexpressed}

The eruption of the theological into logical demonstrates how the power of the aesthetic reacts indifferently in respect to our logical intentions, conscious or unconscious, when the work is actually work.

The eruption of the theological into nihilism demonstrates how the power of the aesthetic redeems the exhausted word and fades in the conceptual impotence. 
The eruption of the theological into architecture demonstrates how the power of the aesthetic subverts the iconological categories (iconic-aiconic) from their atavistic governing contraposition.

Each cultural paradigm is in and of itself iconological, Jewish or GreekChristian. Different and yet the meaning of that iconology. The theology (Jewish and Greek-Christian or otherwise) is the meaning that gives the mark, tone and intonation to that iconological language and, not to some other. The meaning, namely the theological, is non-transferable and irreducible essence. Non-transferable, since it cannot be confused with that belonging to diverse paradigm. Irreducible, since it cannot elude that same paradigm.

Therefore, the introduction of the theological in architecture inevitably undermines many false opinions, in particular the dominant ones (and unfortunately also the unconscious ones) of the nihilist-technical-scientific nature. In the first place it literary omits the distinction, eliminating the artificial separation between the spoken-written-formal word. The theological denounces the inner contradiction of Eisenman's language; it unmasks the logic armor of the written word in opposition to the formal (of the language) word (the architectural work); dissolves the spell of the analytical-rational written word bringing it back to the unity of the aesthetic, the original power. In our case in fact,

$$
\begin{aligned}
& \text { the word spoken limits, } \\
& \text { the word written de-limits, } \\
& \text { the word formal non-limits. }
\end{aligned}
$$

The limitation of the spoken word, the verbal announcement, retains the extremes origin-intention-possibility, although still undefined, in connection between each other, between revelation and elaboration.

The delimiting of the written word isolates the multiple within the profane, separated from the original unity.

Non-limitation of the formal word liberates finally the multiple of the original unity, renewing in the historical becoming the connection between the theological-profane, between revealed and realized.

The immediacy of the aesthetic therefore bypasses the peremptory defensive line of the written word; elevates our minds from the foot to the summit of the wall. That which was previously denied to the eye now is offered to the 
availability of the vision, in the enchantment of contemplation. And only on that appertaining plane of the work Eisenman's language renews the original perception of the linguistic unity (spoken-written-formal)

For the third time, then, Eisenman's thought presents itself inexorably as emblematic. For that same reason we have to start again from the text the End of the Classical. There are three initial assumptions:

- for a timeless architecture, without the origin and without purpose, (as a response to the fiction of the History: the simulation of the eternal),

- for a non-representative architecture, deprived of an object, (as a response to the fiction of the Representation: the simulation of the meaning),

- for an artificial and arbitrary architecture, deprived of reason, (as a response to the fiction of Reason: the simulation of the truth),

- in fact suffer the impetuous twist under the (reviving) rooting impulse of the Jewish theological.

The timeless architecture expresses the rejection of the idea of cyclic and linear time of the Greek-Christian paradigm to turn instead to the idea of historical temporality in the Jewish paradigm. Neither the Greek Aion, nor the Latin Saeculum. But the oLaM: the duration of doing, the assigned and defined temporal dimension that oscillates in the interval between revelation (origin) and redemption (end). The historization of the Event (the work), and not the Form, that will only be achieved in the prefect fulfillment of the $o L a M$, records therefore the relevance of its own presence like a fragment or the frame of the time sequence contained and compressed between the extremes: between "their prehistory and the successive history". That is, the work is inserted in the "original movement of becoming and passing away", in the apocalyptic course between the divine creation and Adam's realization, that are actually a priori extreme conditions which provide the work with its own visuality.

Non-representative architecture expresses the rejection of the figurative tradition (from the metaphysical idea of space) of the Greek-Christian paradigm, in favor of the idea of creation of the Jewish paradigm. And then because that which it creates through the medium of the name or the word, logocentrism assumes the fundamental importance, indispensable and irreplaceable in setting the language and expressive sensibility. Language becomes "the most perfect archive of immaterial similarities" $"$. And Logos designs "the primordial carving" 92 from which extends the "divine handwriting" 93 of the cosmos as the soul and mind. The word in the theological field is then the medium, the symbol between creation and elaboration. Non-representative architecture in 
the Jewish paradigm is a non-sense, since it is absolutely representative. And it cannot be otherwise because of the symbolic of the principle of creation that takes place by means of Logos in which converge in them the beginning and the end, revelation and redemption, "tragic time and Messianic time" 94 . In fact:

- the creation is entrusted to the original project (the theological form);

- the revelation is entrusted to the symbolic word (the internal form);

- the redemption is entrusted to daimon of the work (the external form).

Artificial and arbitrary architecture expresses, in the end, the rejection of any hierarchical and transcendental system implicit in the Greek-Christian paradigm in favor of the self-transparency of the non-expressed in the Jewish paradigm. Self-transparency of the non-expressed is the theological sum (equal to the thermal sum in nature ${ }^{95}$ ) of the principle of creation (the iconological background) with the temporal principle of $o L a M$ (the historical background). Arbitrary and artificial are then two fictitious and provisional terms indicating to the fatigued and complex critical step of the Greek-Christian paradigm towards the Jewish paradigm. Attained, however, in the Jewish theological filed the subjective self-referentiality (prevailing in the divine scope and in the contemporary culture) transforms itself into auto-negation of the subjective. Personal individuality changes the coefficient in the impersonal universality of the work when it is precisely in the scope of the theological. Only in this dimension and only with this condition the work of the "fragment of the symbol" is finally free to appear authentically: to enable transparency in the perception of the idea-word-symbol-form of "non-expression of unintentional truth". Self-transparency of the non-expressed offers then to the work the maximum guarantee of its plastic and expressive freedom only through autonegation of the self. So that the auto-negation does not at all mean annulment of the self. Simply it corresponds to the largest and maximum expansion of the individual Self in the universal Self and finds its fulfillment and its correspondence always new and always unique precisely in the realization of the work. Self-transparency of the non-expressed, impersonality of the work, auto-negation of the self: the three essential requests of the aesthetics of the theological because of profane phenomenal.

Eisenman's work therefore fully belongs to that unexpected and surprising onto-iconological constellation:

the origin, the temporal medium,

the word, the aesthetic medium,

the symbol the expressive medium. 
The primary factors of each semantic prefiguration in the Jewish paradigm, branch out into the immense cosmic embroidery: the unity of the theological. And on this ineffable evil it is deposited:

the unity of work, the unity of knowledge, the unity of language.

We can now make out the glimmer of the response to the initial question. It is precisely the theological that is the noblest category of the aesthetic, where the primitive contrast is between the expressible and inexpressible that should preserve and enhance the episteme of the sense. The Eisenman's wall, with its imposing logical-rational structure, ceases to be a looming confine or the inaccessible "watershed between the river of the language and the river of the revelation" "96. From its summit, divided and separated, the theological and profane, the created and the realized, the unmanifest and the manifest, idea and form, blur their powerful distinction to culminate in "intensive totality" of the metaphysical circle. But that from where one can observe and understand does not depend on the occult or mysterious spell. It rather depends on to be and to exist on the wall. It is the same work with the mass of own construction, with the weight of own presence, with the unmistakable visibility of one own appearance to ensure and perpetuate the renewal of the original silence of the theological. Where it is repeated only owing to the work the miracle for the metaphysical knowledge: "the concrete totality of the experience that is the existence ${ }^{97}$.

And it is precisely existence that jolts in the theological: to make the thrill of life vibrant in immaterial diaphragm interposed between the unfathomable obscurity of creation and the original clarity of perception. The theological announces therefore the impact of each minimal birth imprinting the indelible aspect. For that reason in transition from creation to realization there happens the donation of aesthetic: the divine "moral act"

The theological: not only the pure aesthetics, but above all the pure logics. The undifferentiated unity of the differentiated phenomenal.

Eisenman's work belongs rather de facto then legally to the Jewish theological. If the critics wished to see it only from one side, the analytical-nihilistic, is not the flaw of the work, rather it is the want if not the obstinacy of the contemporary culture. However, the work is here, in front of us, unchanged 
and unchangeable, the witness of its own existence. But the testimony of the work coincides with its muteness: we can only scrutinize the silence, and thereby also the aesthetics, the first presupposition of each meaning.

Much has been said here and elsewhere about the Eisenman's work. But something more should be added.

From the theological viewpoint his work appears as a grandiose temporal form of the universal Jewish history. Much distant from the Tafurian ${ }^{99}$ suspicion and too close to Derrida's question ${ }^{100}$, the language of his architecture represents the most complete and the most powerful form of tragic and Messianic ${ }^{101}$ temporality. A figurative narration extraordinary as per its logical rigor, the aesthetic density, ethical profoundness. Something unique and disturbing on the actual scene although it inverts all of a sudden (and in silence) the sources of the language: from profane to the theological, from functional to the epistemic, from chronological to historical, without rescinding the links. For that reason Eisenman's work is authentically Jewish: historically and originally was placed between the greatest theological extremes: between the revelation (the words) and redemption (the form). And it is no coincidence that Sanford Kwinters ${ }^{102}$ defined it as Kaddish: a solemn prayer, a hymn of praise, a Messianic promise (because of the form). The invocation of time to save from historical annihilation the unexpressed (and the repressed) of the Jewish language.

A second essential aspect of his work concerns the shift in blocks of iconological axis of the Greek-Christian paradigm around the Jewish one. This necessity does not find more satisfaction in simple expressionism of the psychological nature but has to be based on diverse conscious, on new rationality, on new metaphysical logics. A commitment to this, or maybe obsession, which develops in two precise directions: analytical and representative. The two Benjamin's ways to «seek the contents of truth» of the work. In fact, the analytical way was entrusted to writing, and the representative way to the design process. The written word must put on fire the dispositive of the abstract concepts; the representative method the contemplation of the formal procedure. The sum of the two, however, has to find the perfect collimation with the symbolic constellation of the ideas in the Jewish paradigm in an architectural field (for the Jewish culture) as from the beginning. With the emergence of the new iconology Eisenman inaugurated in architecture the first phase of the Jewish classicism. 
But there is another aspect of observation: the historical relevance of his architecture in relation to contemporary nihilism. The appearance on the world scene of Eisenman's work has provoked the most dramatic interpretative misunderstanding which is still ongoing. From the appearance only the semblance was caught, the external envelope, and not the essence, the internal nucleus. Only that the semblance fades on the surface, whereas the essence intensifies in the depth. We could also write: the appearance is the vaguest similarity; the essence is densification of the theological image. For that reason appearance without essence is a similarity without image. In fact a form without image is a work without sense. However, whenever impossible arché and tèlos of the èrgon, the principle and the end of the work, are preservation, protection, custody of that distance which makes that the image of the essence (self-transparency of the unexpressed, the theological) belongs to the figure of appearance. For that reason the work ${ }^{103}$ oscillates and is between the extremes of the theological image and phenomenal figure. For that same reason the technical-scientific nihilism could not but dwell, with its own status, only in the semblance of the disconnected and distant similarity (of the secondary) of the image of the essence (primary ${ }^{104}$ ). With the result of the reversed reading. But we would be beyond the time if we wished to ask from Eisenman's work the anti-nihilism declaration considering that nihilism has always celebrated it even if only by half.

The Eisenman's wall draws a thin line between the empire of meaning (the similarity) and the kingdom of the sense (the image). Whether we will by-pass or respect it depends only on us. Once beyond, however, nothing can be the same any longer. 

the distance, the fascination; the transcendence of the real, the work Aesthetics: intensive like metaphysical-ontological unity. Walter Benjamin, Opere complete - vol.I, Le affinità elettive di Goethe (Einaudi, 2008), 523. The real is the maximum density, the pointed tip of the arrow of the' essential. With metaphysical-surrealism relation in the art of Renè Magritte, it is referred to the book of Massimo Donà, Il mistero dell'esistere (Mimesis, 2006).

Benjamin, vol. I, Il compito del traduttore, 506.

Benjamin, vol. I, Il compito del traduttore, 510. «As the tangent touches the circumference on its way and only in one point, and same as this contact, but not the point, prescribes its law , because of which it continues to the infinity its right way, so that the translation (interpretation) touches the original only in passing and only in the infinitely small point of sense, to continue, in accordance with the law of fidelity, in the freedom of linguistic movement, its own life». Benjamin, vol. I, Il compito del traduttore, 512-513.

Ibid., 539 - 544. 
nihilism.

Benjamin, Opere complete - vol.I, Due poesie di Hölderlin, 217.

Benjamin, Opere complete - vol.I, Le affinità elettive di Goethe, 523.

Ibid., 523.

Translated into Eisenman's language it becomes palimpsest: the theoretical concert which then transforms into scaling, the principle of the «mystic» and regular composition

Ibid., 523.

Ibid., 524.

Ibid.

In the original text it reads «meaning». As it was not yet introduced in our essay the difference between the sense (the universal relation) and the meaning (individual relation) it was necessary to substitute the term.

Ibid.

Benjamin, Opere complete - vol.I, Due poesie di Hölderlin, 235.

Benjamin, Opere complete - vol.II,Il dramma del barocco tedesco, Premessa gnoseologica, 69-96.

Ibid., 71. «The truth, actualized in the crowd of the represented ideas, escapes any projection within the knowledge. The knowledge is property. Its very object (...) has to be possessed, in a transcendental way, in the conscience». «The conscience can be questioned, but not the truth». Ibid., 70. « The value of the individual fragments of thought the more it is decisive the less their relation is immediate with all together, and the brilliance of the performance depends on the value of these fragments same as the splendor of the mosaic depends on the quality of forged glass. The relation between micrological elaboration and the global form expresses the law according to which the contents of truth of a theory may be discerned only in the most precise penetration of the individual details of the concept. In its maximum blooming in the West, the mosaic and the treaty belong to the Medieval Age, that which permits their confrontation is an authentic relationship».

Benjamin, Opere complete - vol.I, Il significato del linguaggio nel Trauerspiel e nella tragedia, 279.

Benjamin, Opere complete - vol.II, Il dramma del barocco tedesco. In, Dramma e tragedia (I), 97.

Benjamin, Opere complete - vol.II, Premessa gnoseologica, 75.

Ibid., 75.

Ibid., 76.

Ibid.

Ibid.

Ibid.

Ibid., 77. «To say that idea is a monad briefly signifies: each idea contains the image of the world. Its task is the representation, nothing less than to draw in short that image of the world. P. 88. However, «the ideas constitute the irreducible multiplicity».

Ibid., 75.

Ibid., 80.

Ibid, 76-77.

Ibid., 77.

Ibid. "In the empirical perception, in which the words are decomposed, to the words inherent are, besides its more or less symbolic meaning, added profane explicit meaning».

Ibid. "The task of the philosopher is to restitute its lead, through representation, to the symbolic character of the word: that character in which the idea reaches as far as self-transparency, which is contrary to communication addressed to the exterior".

Ibid., 87.

Benjamin, Opere complete - vol.I, Allegoria e dramma barocco, 196.

Ibid., 200. 
Benjamin, Opere complete - vol.I, Sulla lingua in generale e sulla lingua dell'uomo, 283.

Benjamin, Opere complete - vol.II, 201.

Ibid., 77.

Ibid., 78.

Ibid.

Ibid., 87.

Carlo Enzo, Adamo, dove sei? (Il Saggiatore, 2002). Biblical exegesis conducted by Carlo Enzoin the original text in Hebrew of Tanaka undermines the roots of the secular beliefs and prejudices, demonstrating unexpected and unsuspected constellations of links and relations. In particular the relation between project-creation-revelation-elaboration-realization, the Adam's task in the laic time so that the work really becomes the image through the process of similarity. Fundamental and very actual theme of our time.

Benjamin, Opere complete - vol.I, Sulla lingua in generale e sulla lingua dell'uomo, 281-295.

Ibid., 281.

Ibid., 286.

Ibid.

Ibid.

Ibid., 288.

Ibid.

Ibid., 287.

Ibid.

Ibid., 288.

Ibid., 292-293.

Benjamin, Opere complete - vol.I, Il compito del traduttore, 509.

Ibid., 288-289.

Benjamin, Opere complete - vol.I, 597.

Ibid., 594.

Ibid., 593.

Ibid.

Ibid.

Ibid. 595.

Ibid. 597.

Ibid. 597.

Extension is the relation with the epic; the depth with the lyric. Franz Rosenzweig, La Stella della Redenzione (Marietti, 1985), 263.

Pieter Eisenman, "The End of the Classical," Perspecta 21(1984). (Italian translation published in the volume by)Traduzione italiana nel volume edito da Cluva, Ve 1987: Pieter Eisenman, La Fine del Classico, pp. 145-169. A cura di R. Rizzi.

Ibid, 145.

Ibid, 157. Although Eisenman declares inutility of proposing the alternative model, in fact he proposes one.

Ibid, 162.

Ibid, 158.

Günther Anders, Kafka, pro e contro (Quodlibet, 2006), 30.

Ibid, 31.

For the text in the original language he refers to the magazine Blueprint, February 1985, and, partially, in concluding the essay L'Eresia nascosta.

Pieter Eisenman, La Fine del Classico, 204.

He refers to the essay Mistico nulla nel which deals with analytical progressive and comparative evaluation of the linguistic development of Eisenman's aesthetic-formal principles.

Pieter Eisenman, La rappresentazione del dubbio: nel segno del segno, 43-55.

Benjamin, Benjamin, Opere complete - vol.I, 292. 
Ibid., 292.

Cfr. Mistico Nulla.

Benjamin, Opere complete - vol.I, 292-293.

The difference between iconic and a-iconic absolutely has no sense, because iconic difference depends on the referencing paradigm. In our case on Greek-Christian or Jewish paradigm.

F. Rosenzweig, La Stella della Redenzione (Marietti, 1985),110.

Ibid, 113 .

Ibid, 204.

Giulio Busi, Qabbalah visiva (Einaudi, 2005)

Giulio. Busi, Simboli del Pensiero Ebraico (Einaudi, 1999). In particular, the interpretation of the Lurianic doctrine (XVI century) relative to the four cosmogony symbols: Sefirot, Tzimtzum, Shevirat ha-kelim, Tiqqun.

Benjamin, Vol.V, 524.

Giulio Busi, Qabbalah visiva (Einaudi, 2005), 5.

Ibid, p. 5.

Benjamin, Opere complete - vol.I, 274. «The tragic time is the time spent by and individual, whereas the Messianic time is divinely spent time».

The theological summary can be compared to the thermal summary in nature: the quantity of energy which each plant or seed needs to accumulate in order to be born.

Benjamin, Opere complete - vol.I, 511.

Ibid., 340 .

Ibid., 594.

"Beyond this process, which can be stopped at any point (...), there is nothing else to show". "behind such process (refers to House X), which can be interrupted at any moment (...), there is nothing else to show". The ideological-political suspicion of Manfredo Tafuri does not succeed in breaking the appearance of Eisenman's work. Manfredo Tafuri, "The Meditations of Icarus," in Houses of Cards, by Peter Eisenman (Oxford University Press, 1987).

"My question therefore relates not only to the absence or the presence, but to God". "I would like, therefore, Peter, (...) to hear you talking about the passages of the relationship between architecture, today, and poverty, all forms of poverty, the one Benjamin talks about" (Esperienza e povertà, cfr. nota 8 ). The questions addressed by Jaques Derrida to Peter Eisenman on Man, God, Poverty, would find in the theological-aesthetic dimension (the original ethical dimension, de-teologization of the religious and political, classical de-ontologization!) a radically diverse response. Jaques Derrida, 'Letter to Peter Eisenman," in Choral Works (Monacelli, 1997); now in Italian for Scheiwiller, Adesso l'architettura, 2008, 203, 210.

See note 95

Sanford Kwinter, 'Kaddish (For an Architecture not Born)," Bookforum 10, n 4 (2003). Another epistemological question would open up in respect to the work. To emphasize only to the relation among work-image-figure. The work which pertains to creation,; the image which pertains to the theological; the figure which pertains to the phenomenal.

The dualism «primary-secondary» is referred to the work of George Steiner, Vere Presenze (Garzanti, 1992). 
Anders, Günther. Kafka, pro e contro. Quodlibet, 2006.

Benjamin, Walter. Opere complete - vol.I, Le affinità elettive di Goethe. Einaudi, 2008.

Busi, Giulio. Qabbalah visiva. Einaudi, 2005.

Busi, Giulio. Simboli del Pensiero Ebraico. Einaudi, 1999.

Derrida, Jaques. 'Letter to Peter Eisenman." in Choral Works. Monacelli, 1997.

Enzo, Carlo. Adamo, dove sei?. Il Saggiatore, 2002.

Eisenman, Pieter. "The End of the Classical." Perspecta 21(1984).

Kwinter, Sanford. 'Kaddish (For an Architecture not Born)." Bookforum 10, n 4 (2003).

Rosenzweig, Franz. La Stella della Redenzione. Marietti, 1985.

Steiner, George . Vere Presenze. Garzanti, 1992.

Tafuri, Manfredo "The Meditations of Icarus." in Houses of Cards, by Peter Eisenman. Oxford University Press, 1987. 
JEVREJSKI ZID:

Ajzenmanovo carstvo

\section{Renato Rizzi}

U ovom radu, autor se zalaže da i arhitektura, kao i druge estetske discipline, već dugo ukazije na prvobitni problem: osećaj forme. Forma se smatra mnoštvom ekspresivnih jezika koji potiču od određene vrste znanja. Arhitektura je viđena kao rad realizacije, saznanje znanja, a forma je prezentacija, suština je u osećaju.

Autor tvrdi da je više promenljiv, mada ne jedini među četiri faktora, pravo na znanje. Ako se više ili manje proširi i produbi, veća je ili manja naša sposobnost da klizimo duž osnovne linije. Ili ka "sadržaju istine jednog dela", prema rečima Valtera Benjamina. Pretpostavka, iako tek treba da se dokaže, nameće logiku mišljenja kojoj treba pridružiti estetiku mišljenja: poklon sastavljanja, slika jedinstva celine.

U nekoliko delova, preko teoloških pitanja, scena mišljenja, tumačenja o zastupanju i razmišljanju, ideja, koncepata i fenomena, autor diskutuje o mogućim tumačenjima rada Pitera Ajzenmana.

KLJUČNE REČI: TELOS, IKONOLOGIJA, EPISTEMOLOŠKA PREMISA, FORMA, INTERPRETACIJA, TEOLOGIJA, JEVREJSKA PARADIGMA, GRČKO-HRIŠĆANSKA PARADIGMA

ARHITEKTURA I FILOZOFIJA:

Paradoksi i metamorfoze njihovog sastanka

\section{Chris Younès}

Poznato je da je Žak Derida (Jacques Derrida) istakao ideju suštinskog suživota između filozofije i arhitekture, izjavljujući: „Collège inetrnational de philosophie bi trebalo da obezbedi mesto za sastanke (recontre), sastanak razmišljanja, između filozofije i arhitekture. Ne da bi se konačno sukobljavale, već da se razmišlja o onome što ih je oduvek održavalo zajedno u najsuštinskijem suživotu." Ovaj rad se posebno bavi hipotezom o metamorfozi ovog sastanka da, od jedinstva arhitektonike i principa, postaje mnogostrukost i drugog karaktera. Tako da je tu preispitivanje u smislu granica i prolaza; drugim rečima, u smislu otvaranja. Prvi sastanak se može smatrati kao metaforička igra ogledala u kojoj svako predstavlja sebe kao prevlađujući u odnosu na druge oblike znanja - jedan kao nauke o teoriji, drugi kao nauke o tehnikama. Ovo uređeno i orijentisano poziranje će propasti u isto vreme sa nestankom konačnog kosmosa. U tom raspadu, arhitektura i filozofija su se 
prekomponovale da bi se bavile prostorom i vremenom naseljenih sredina koje utiču ne samo na konstituciju pogleda, već isto tako na transformaciju sveta. Istražuje se kako je njihov interfejs heuristička struktura ispitivanja.

KLJUČNE REČI: FILOZOFIJA, ARHITEKTURA, GRANICE, PROLAZI, METAMORFOZA

\section{MARGINE ARHITEKTURE}

\section{Maurizio Ferraris}

Polazeći od primera naročito ružne Palazzo Nuovo u Torinu, ovaj rad ima za cilj da predstavi, putem poređenja između arhitekture i vizuelnih umetnosti, deset interpretacija (konceptualnost, auralnost, suplementarnost, neodgovornost, pareregonalnost, autorijalnost, podređenost, dokumentalnost, piramidalnost, stvarnost), koje opisuju karakteristike savremene arhitekture kao što i ukazuju na određene granice i pravila sa kojima arhitektura mora da se pomiri.

KLJUČNE REČI: ARHITEKTURA, FILOZOFIJA, VIZUELNE UMETNOSTI,

DOKUMENTALNOST,STVARNOST, DERIDA, ESTETIKA

ZAKON OIKOSA.

Žak Derida i Dekonstrukcija Stanovanja

\section{Francesco Vitale}

Ovaj rad skicira bitne linije rada koji je u toku a koji ima za cilj da prati putanju koju je otviro Derida ka dekonstrukciji stanovanja. Nameravam da pokažem kako je Deridina briga za arhitekturu strogo povezna sa urgentnošću dekonstrukcije stanovanja koja naseljava njegov rad od najmanje Platonove Farmacije (1966), pa nadalje. Prema Deridi, i filozofija i arhitektura su podređene arhaičnoj koncepciji stanovanja koja još uvek opseda naš način razmišljanja i izgradnje mesta stanovanja (teritorija, grad, kuća) i, na taj način, utiče na političku dimenziju našeg života.

KLJUČNE REČI: STANOVANJE, DEKONSTRUKCIJA, KHORA, ONTO-TOPO-POLITIKA, PROSTOR

\section{LA NAVE DI PIETRA/ KAMENI BROD}

\section{Zoran Lazović:}

Svet se stalno gradi i razgrađuje. Da li postoji suštinski paradoks dekonstruktivizma u kreativnim radovima arhitekata? Čemu odgovara arhitektonski projekat? Dnevnik priče u kojoj je pripovedač svoj sopstveni tumač:Od neizvesnog prisećanja i izbledelih kopija do višestrukih novih 
originala. Gde je bio Vavilon arhitekte? Grupni portret. Kriegs Insel in Plannen, Isključenje iz zemaljskog Raja. Blok 24. Kulturni centar Tré́eg Milenijuma. Futuristički pristup Savskom amfiteatru Tré́eg Milenijuma. Urbana Utopija: Omaž gradu Vukovaru. Grad Nade. Cauchemare - košmar. Noćni rad. Imago mundi. Opservatorija budućnosti? Lutanje i život na niskoj frekvenciji. Beogradska Nekroza i Smrt Srbije. Paralela introspekcije, ili smrt mnogih svetova pred nama. Oni koji ne mogu da vide da će umiranje videti neke druge svetove kako nestaju: njihovo propadanje, rastavljanje, nestanak. Pogled u ambis prošlosti: radi nekog traga, ili radi nešto više tragova uporedno. Arhitektura. Slike. Fragmenti. Hibridi. Svedočenje očuvanih slika, objekata, arhitektonskih kompozicija, ikonografskih fragmenata, montaža, sklopova, umetničkih kolaža, mentol brikolaža. Odraz velikih događaja i ideja: neprekidno menjajujući i nestajući Kontekst. Kontekst velikih pokreta. Moda. Trendovi.Glavne tendencije. Ratovi. Kreativni prioriteti i vizije. Lekcija iz anatomije: sučavanje sa sopstvenim projektima i konstruktima, vezivanje, analiza, dekonstrukcija, reminiscencija i rekonstrukcija, se-ćanje (ponovno vraćanje delova celine). Neki trag već uništenog postojanja i neizbežnog nestajanja. Da li postoji iščekivanje i predviđanje događaja i raspadanje, odlazak i povratak? Kakvi su to ramovi imali slike koje su bile nevidljive u to vreme? Pratiti trag kroz Spektar Deride.

KLJUČNE REČI: ARHITEKTURA, IDEJE, KONCEPTI, KONTEKSTI, DEKONSTRUKCIJE, DESTRUKCIJE, RETROSPEKTIVA 